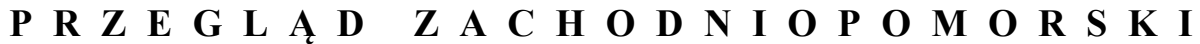 ROCZNIK XXXIII (LXII) ROK 2018 ZESZYT 1
}

\author{
ZBIGNIEW GŁĄBIŃSKI \\ Uniwersytet Szczeciński, Wydział Nauk o Ziemi \\ e-mail: zbigniew.glabinski@usz.edu.pl
}

\section{STOSUNEK MIESZKańców POWIATU GRYFIŃSKIEGo DO ROZWOJU TURYSTYKI W ŚWIETLE BADAŃ JAKOŚCIOWYCH}

Słowa kluczowe: planowanie rozwoju turystyki, postawy mieszkańców, badania jakościowe Keywords: planning the development of tourism, residents' attitudes, qualitative research

\section{Wprowadzenie}

Rozwój turystyki w regionach jest powszechnie postrzegany jako zjawisko korzystne w różnych aspektach ${ }^{1}$ :

- ekonomicznym-poprzez podniesienie poziomu jakości życia mieszkańców,

- społeczno-kulturowym związanym z nawiązywaniem relacji pomiędzy mieszkańcami i turystami,

- infrastrukturalno-usługowym poprzez poprawę infrastruktury i jakości usług oferowanych mieszkańcom.

1 A. Niezgoda, Badanie opinii mieszkańców Poznania dotyczacych rozwoju funkcji turystycznej, w: Sposoby mierzenia i uwarunkowania rozwoju funkcji turystycznej miasta, red. G. Gołembski, Wydawnictwo UEP, Poznań 2011, s. 107-146. 
Badania dotyczące stosunku lokalnych społeczności do rozwoju turystyki prowadzone są w bardzo szerokim zakresie na całym świecie ${ }^{2}$, w tym również w Polsce 3 .

Wyniki przeprowadzonych dotychczas badań wskazują na to, że większość lokalnych społeczności cechuje pozytywny stosunek do rozwoju turystyki ${ }^{4}$. Istnieje jednak wiele czynników różnicujących postawy poszczególnych przedstawicieli lokalnych społeczności. Wśród nich badacze wymieniają m.in.:

- długość zamieszkania na danym terenie i miejsce urodzenia,

- stopień poczucia tożsamości lokalnej i regionalnej,

- stopień przywiązania do lokalnej społeczności,

- stosunek do rodzaju walorów turystycznych (przyrodniczych lub społeczno-kulturowych).

Jednym $\mathrm{z}$ regionów o szczególnych uwarunkowaniach społecznych w tym zakresie jest Pomorze Zachodnie. Wynika to z przerwania ciągłości historycznej spowodowanej całkowitą wymianą ludności jaka dokonała się po drugiej wojnie

2 D.R. Williams, C.D. McDonald, C. Riden, M. Uysal, Community attachment, regional identity and resident attitudes toward tourism, "Proceeding of the 26th Annual Travel and Tourism Research Association Conference Proceedings" 1995, s. 424-428; K.L. Andereck, G.P.S. Nyuapane, Exploring the Nature of Tourism and Quality of Life Perception among Residents, „Journal of Travel Research" 2011, vol. 50, nr 3; S.K. Gupta, V. Prakash, Assessment of rural destination residents' attitude toward tourism development in Uttarakhand, India: a research note, „International Journal of Qualitative Research in Services" 2014, vol. 1, nr 3; I. Marković, Z. Klarić, Attitudes of Local Population of Tourism Impacts on Destination Sustainability - Case of Croatia, „Turizam” 2015, vol. 19, z. 3; B. Zeinali, M. Jafarpour, E. Omidi, N. Tahmasbi, S. Dorangard, Will Tourism Development Improve the Quality of Life in Hashtpar City? An Analysis of Local Residents' Attitudes, „International Journal of Economy, Management and Social Sciences" 2015. vol. (4), nr 3.

${ }^{3}$ K. Komorowska, Turystyka a społeczności lokalne - przyktad tatrzański, „Studia Regionalne i Lokalne" 2003, nr 3 (13); A. Niezgoda, Badanie opinii...; I. Sikorska-Wolak, J. Zawadka, Postawy społeczności lokalnej wobec rozwoju turystyki wiejskiej, „Folia Pomeranae Universitatis Technologiae Stetiniensis. Oeconomica” 2011, nr 288 (64), s. 93-102; M. Mika, Postawy spoteczności lokalnych wobec turystów i rozwoju turystyki - przykład gmin Beskidu Śląskiego, „Prace Geograficzne IG i GP” 2013, z. 134; A. Tucki, E. Skowronek, R. Krukowska, Ocena postaw społeczności lokalnej do rozwoju turystyki na przykładzie Zwierzyńca, w: Gospodarka turystyczna $w$ regionie. Rynek turystyczny - współczesne trendy, problemy i perspektywy jego rozwoju, red. A. Rapacz, Prace Naukowe Uniwersytetu Ekonomicznego we Wrocławiu, Wrocław 2013.

4 Y. Wang, R. Pfister, D. Morais, Residents Attitudes Toward Tourism Development: A Case Study of Washington, NC, "Proceedings of the 2006 Northeastern Recreation Research Symposium" 2006; K.P.L. Chandralal, Impacts of Tourism and Community Attitude towards Tourism: A Case Study in Sri Lanka, „South Asian Journal of Tourism and Heritage” 2010, vol. 3, nr 2; K.L. Andereck, G.P.S. Nyuapane, Exploring the Nature ...; A. Niezgoda, Badanie opinii mieszkańców...; I. Sikorska-Wolak, J. Zawadka, Postawy społeczności lokalnej...; M.H. Hanafiah, M.A. Hemdi, Community Behaviour and Support towards Island Tourism Development, „International Journal of Social, Behavioral, Educational, Economic, Business and Industrial Engineering” 2014, vol. 8, nr 3; M. Mika, Postawy społeczności...; B. Zeinali, M. Jafarpour, E. Omidi, N. Tahmasbi, S. Dorangard, Will Tourism.... 
światowej. Jak podkreśla H. Rogacki, było to w skali Europy zdarzenie bez precedensu ${ }^{5}$. Powstała dość niezwykła sytuacja, w której ludność napływowa przejęła dziedzictwo kulturowe tworzone w ciągu wielu wieków i będące dorobkiem wielu narodów. Była to znacznym stopniu obca spuścizna historyczna i kulturowa kojarzona przez nowych osadników z żywiołem germańskim. Spowodowało to swoisty konflikt pomiędzy dziedzictwem należącym do poprzednich społeczności, a nowymi mieszkańcami Pomorza Zachodniego. Jak podkreśla Z. Mazur, „zastany krajobraz nie przemawiał ani do serca ani do rozumu”. Po drugiej wojnie światowej bardzo wrogi stosunek do Niemców przenosił się na dobra materialne pozostawione przez byłych gospodarzy tych ziem. Należy zauważyć, że jedynym elementem dziedzictwa, którego nie dotyczył negatywny stosunek społeczeństwa było budownictwo sakralne?

Na to wszystko nakładała się polityka ówczesnych władz Polskiej Rzeczypospolitej Ludowej, które popierały niszczenie śladów niemieckości. Co więcej niestabilna sytuacja polityczna była przyczyną, że nawet nie rozpoczęto odbudowy wielu zniszczonych obiektów przemysłowych lub użyteczności publicznej, a zamiast tego wyposażenie fabryk wywożono do Polski centralnej ${ }^{8}$. To zjawisko było szczególnie widoczne na przygranicznych obszarach ówczesnego województwa szczecińskiego. $\mathrm{Z}$ tego m.in. powodu na początku lat pięćdziesiątych XX wieku nadgranicznie Gryfino, położone w cieniu Szczecina, zwane było „kopciuszkiem” województwa. Przyczyną tej sytuacji był m.in brak decyzji o odbudowie zniszczonej infrastruktury oraz powstania nowych inwestycji ${ }^{9}$. Do 1960 roku nie powstał w tym mieście żaden nowy budynek, a dopiero pod koniec lat sześćdziesiątych zakończono odgruzowanie terenu.

Jednym z najważniejszych zaniechań o charakterze gospodarczym w powiecie gryfińskim była decyzja ówczesnych władz o zaniechaniu odbudowy, zachowanych w dość dobrym stanie technicznym, zakładów papierniczych w Osinowie

5 H. Rogacki, Przesunięcia w strukturze i hierarchii miast województwa zachodniopomorskiego w latach 1810 -2000, „Przegląd Zachodniopomorski” 2003, z. 4.

6 Z. Mazur, Dziedzictwo wytaczne, podzielone, wspólne, w: Ze studiów nad stosunkiem spuścizny kulturowej na Ziemiach Zachodnich i Pólnocnych, red. Z. Mazur, Poznań 2000.

7 Z. Głąbiński, Szkolny ruch turystyczno-krajoznawczy jako czynnik ksztaltowania tożsamości regionalnej na przykładzie województwa zachodniopomorskiego, Szczecin 2008, s. 17-18.

8 A. Makowski, Dzieje miasta w Polsce Ludowej, w: Dzieje Gryfina i okolic, red. P. Kołosowski, Gryfino 2009, s. 167-190.

9 Tamże, s. 173-178; A. Makowski, Cedynia ofiara ,zimnej wojny”?, w: Cedynia i okolice poprzez wieki, red. P. Migdalski, Szczecin 2013, s. 225-239. 
Dolnym. Ta inwestycja mogła całkowicie zmienić społeczno-gospodarczy obraz analizowanego obszaru i przyczynić się do jego znacznej aktywizacji ${ }^{10}$. Niestety przygraniczne położenie Osinowa, z punktu widzenia władz centralnych w Warszawie, było głównym mankamentem tej lokalizacji. Do dzisiaj zachowały się ciągle niewykorzystane ruiny tego obiektu.

Przygraniczne położenie powiatu gryfińskiego wpływało nie tylko na ograniczenie perspektyw ekonomicznych, ale wiązało się też z wieloma ograniczeniami natury administracyjnej dotyczącej poruszania się mieszkańców i osób przyjezdnych $^{11}$. Te wszystkie czynniki wpływały negatywnie na atrakcyjność osadniczą i turystyczną całego powiatu gryfińskiego.

Sytuacja zaczęła się zmieniać na lepsze dopiero po 1956 roku, w związku ze zmianami politycznymi w całej Polsce. Nastąpiło niewielkie ożywienie gospodarcze, a w niektórych miejscowościach, m.in. Gryfinie, zaczęły powstawać nowe budynki mieszkalne, które zdecydowanie poprawiły warunki życia mieszkańców.

$\mathrm{Na}$ zasadniczą zmianę sytuacji społeczno-ekonomicznej w powiecie gryfińskim trzeba było jednak poczekać do początku lat siedemdziesiątych XX wieku. Jedną z najważniejszych decyzji politycznych o wymiarze ekonomicznym stała się lokalizacja budowy dużej elektrowni węglowej w Nowym Czarnowie w pobliżu Gryfina, co spowodowało zasadnicze zmiany w rozwoju tej części powiatu. Budowie towarzyszyły liczne inwestycje uzupełniające przede wszystkim budownictwo mieszkaniowe, szkolnictwo, powstawały nowe placówki handlowo-usługowe, obiekty komunalne i kulturalne oraz rekreacyjne.

Drugi korzystny fakt dla rozwoju regionu i zmiany świadomości mieszkańców miał charakter zdecydowanie bardziej symboliczny - były to obchody tysięcznej rocznicy bitwy pod Cedynią w 1972 roku $^{12}$. Przypomnienie słynnej zwycięskiej bitwy Mieszka I po raz pierwszy tak dobitnie sprzyjały poczuciu, że dziedzictwo tej ziemi jest choćby w jakiejś części związane z historią Polski. Propagowanie pamięci o historycznej bitwie sprzyjało ograniczaniu wśród mieszkańców poczucia tymczasowości i niepewności istnienia polskiej państwowości

${ }^{10}$ A. Makowski, Cedynia ofiarą..., s. 225-239.

${ }^{11}$ M. Dźwigał, Granica, w: Spacerem po Dolinie Miłości, red. R. Matecki, Szczecin 2013, s. 83-85; A. Makowski, Dzieje miasta..., s. 174; M. Filipowiak, K. Piekarz, P. Rybak, Z dziejów organizacji stużby granicznej w Cedyni, w: Cedynia i okolice..., s. 253-268.

${ }^{12}$ T. Białecki, Garść wspomnień z obchodów tysięcznej rocznicy bitwy pod Cedynia, w: Cedynia i okolice poprzez wieki..., s. 309-314. 
na tych ziemiach. Bitwę pod Cedynią ówczesne władze PRL połączyły z historią forsowania Odry w 1945 roku przez polskich żołnierzy. Te fakty w przekazie propagandowym PRL zostały potratowane jako klamra spinająca tysiącletnią historię zmagań polsko-niemieckich na granicy zachodniej.

Miało to zasadnicze znaczenie dla form rozwoju turystyki na analizowanym obszarze. Powstał wówczas tzw. Rejon Pamięci Narodowej obejmujący miejsca zmagań polskich żołnierzy w 1945 roku - Czelin, Gozdowice, Siekierki, Stare Łysogórki i oczywiście miejsce bitwy pod Cedynią. Teren ten aż do początku lat dziewięćdziesiątych XX wieku był odwiedzany regularnie i na skalę masową przez wycieczki szkolne z terenu ówczesnego województwa szczecińskiego oraz całej Polski. Obchody kolejnych rocznic stały się okazją do akcentowania prawa przynależności tych ziem do Polski, a ich celem było kształtowanie świadomości terytorialnej mieszkańców. Ubocznym skutkiem traktowania obchodów rocznicowych jako elementu propagandowego stało się zmniejszenie zainteresowania tym obszarem przez turystów po 1989 roku.

Nie udało się jednak zrealizować celu jakim było zbudowanie tożsamości regionalnej mieszkańców. Jak twierdzi J. Leoński, oderwanie przybyłych po 1945 roku nowych mieszkańców Pomorza Zachodniego od korzeni spowodowało, że wzory zachowań społecznych z przeszłości w nowym miejscu stały się bezużyteczne $^{13}$. Tradycje, zwyczaje i zachowania przeniesione $\mathrm{z}$ innej rzeczywistości nie odpowiadały nowym realiom przyrodniczym, społecznym i kulturowym. Ten stan mimo upływu lat zmienia się bardzo powoli, czego przejawem jest niski poziom odczuwania tożsamości regionalnej mieszkańców województwa zachodniopomorskiego ${ }^{14}$.

Po zasadniczej zmianie w 1989 roku realiów społeczno-ekonomicznych w Polsce, problem ścieżki rozwoju społeczno-ekonomicznego dzisiejszego powiatu gryfińskiego pozostał kwestią otwartą. Z jednej strony nadzieje związane z gospodarką rynkową, a z drugiej obawy o próbę restytucji dóbr przez byłych mieszkańców nadal nie sprzyjały rozwojowi społeczno-gospodarczemu.

Doskonałą ilustracją perturbacji związanych z brakiem pomysłów na wykorzystanie istniejącego dziedzictwa historycznego jest m.in. zamek w Swobnicy ${ }^{15}$.

${ }^{13}$ J. Leoński, Kilka socjologicznych uwag o świadomości regionalnej mieszkańców Pomorza Zachodniego, w: Integracja i tożsamość. Zachodniopomorskie w przededniu rozszerzenia Unii Europejskiej, Materiały I Kongresu Zachodniopomorskiego, Szczecin 2003.

${ }^{14}$ Z. Głąbiński, Szkolny ruch turystyczno-krajoznawczy...

${ }^{15}$ R. Czejarek, Swobnica, Szczecin 2013. 
Obiekt po 1945 roku zachował się w bardzo dobrym stanie, ale brak odpowiednich działań konserwatorskich, a nawet celowej dewastacji doprowadził go na początku lat dziewięćdziesiątych XX wieku na skraj ruiny. W rynkowej rzeczywistości panaceum na ten problem miał być prywatny inwestor zagraniczny. Niestety okazało się, że władze gminy się srodze na nim zawiodły i po ponad 20 latach odzyskały obiekt, a następnie podjęły działania restauratorskie. Jednym z niewielu pozytywnych przykładów odzyskania dawnej świetności przez obiekty zabytkowe jest klasztor w Cedyni, który obecnie pełni funkcję hotelu lub odbudowa kościoła N.M.P. w Chojnie.

Zdecydowanie większe sukcesy zanotowano w dziedzinie ochrony walorów o charakterze przyrodniczym, czego dowodem było m.in. utworzenie w 1993 roku Parku Krajobrazowego Dolina Dolnej Odry oraz Cedyńskiego Parku Krajobrazowego $^{16}$. Obszary te dzięki systematycznej popularyzacji walorów oraz rozbudowie infrastruktury turystycznej stały się terenami atrakcyjnymi dla turystów.

Szczególnie po przystąpieniu Polski do Unii Europejskiej władze powiatu gryfińskiego i poszczególnych gmin przystąpiły do coraz intensywniejszych działań służących podniesieniu poziomu życia mieszkańców. Jednym z pomysłów na rozwój były inwestycje w infrastrukturę turystyczną, które w zamierzeniach powinny wpłynąć na wzrost ruchu turystycznego. Zmieniło się także postrzeganie Odry i granicy na tej rzece nie jako czynnika ograniczającego, ale aktywizującego pod względem społecznym i ekonomicznym ${ }^{17}$. To wszystko spowodowało, że mieszkańcy i władze samorządowe zaczęli patrzeć na gospodarkę turystyczną jako na czynnik dynamizujący życie społeczno-ekonomiczne. Mimo pewnych optymistycznych symptomów istnieje wiele pytań oraz wątpliwości czy i jak rozwijać turystykę w regionie.

\footnotetext{
2008.

${ }^{16}$ M. Duda, T. Duda, Dolina dolnej Odry - przewodnik krajoznawczy dla aktywnych, Gdynia

${ }^{17}$ Strategia rozwoju turystyki na poziomie lokalnym. Przykład powiatu gryfińskiego, red. Z. Głąbiński, D. Szostak, T. Zalewski, Warszawa 2016.
} 


\section{Stosunek mieszkańców do rozwoju turystyki - problemy teoretyczne i metodologiczne}

Badacze podkreślają, że istnieje rosnąca potrzeba badania i uwzględniania postaw mieszkańców wobec rozwoju turystyki, szczególnie na tych obszarach, które znajdują się w początkowej fazie rozwoju turystyki ${ }^{18}$. Jest to szczególnie ważne, gdyż lokalnej społeczności nie należy postrzegać jako przeszkody w planowaniu rozwoju turystyki. Co więcej, mieszkańców należy próbować edukować, ponieważ często ich negatywna postawa wobec rozwoju turystyki wynika z braku wiedzy i uprzedzeń.

W procesie planowania rozwoju turystyki należy także uwzględniać lokalne, specyficzne czynniki, które mogą powodować różne postawy wobec tego zjawiska ${ }^{19}$. Jak zauważają I. Marković i Z. Klarić, turystyka rozwija się przede wszystkim na najbardziej atrakcyjnych pod względem turystycznym terenach ${ }^{20}$. W związku z tym zdarzają się sytuacje, że w działaniach z tym związanych ignorowane są lokalne uwarunkowania społeczne. Takie zjawiska mogą prowadzić do nadmiernego rozwoju turystyki na obszarach atrakcyjnych turystycznie, bez uwzględniania uwarunkowań o charakterze społeczno-kulturowym. Należy pamiętać, że to społeczność lokalna w dużej mierze decyduje o rozwoju turystyki na danym obszarze, a więc bez szczegółowego rozpoznania potrzeb i oczekiwań mieszkańców nie jest możliwy zrównoważony rozwój turystyki ${ }^{21}$.

Jednym z powszechnie stosowanych wskaźników do oceny postawy mieszkańców wobec rozwoju turystyki jest model Doxeya (ang. Doxey’s Irridex ) ${ }^{22}$.

${ }^{18}$ R. Harrill, Residents' Attitudes toward Tourism Development: A Literature Review with Implications for Tourism Planning, „Journal of Planning Literature” 2004, vol. 18, nr 1, s. 1-15; R. Sharpley, Turystyka i środowisko, w: Zarzadzanie turystyka, red. L. Pender, R. Sharpley, Warszawa 2008; K.P.L. Chandralal, Impacts of Tourism ...; A. Niezgoda Badanie opinii...; A. Tucki, E. Skowronek, R. Krukowska, Ocena postaw...; I. Marković, Z. Klarić, Attitudes of Local...

${ }^{19}$ R. Harrill, Residents' Attitudes toward...; R. Sharpley, Turystyka i środowisko...; A. Niezgoda, Badanie opinii...; J. Brankov i in., Sustainable Tourism in National Park Derdap, SerbiaAttitudes of Local Population, ,Journal of the Geographical Institute Jovan Cvijic” 2015, nr 65 (2); B. Zeinali, M. Jafarpour, E. Omidi, N. Tahmasbi, S. Dorangard, Will Tourism....

${ }^{20}$ I. Marković, Z. Klarić, Attitudes of Local....

${ }^{21}$ R. Harrill, Residents' Attitudes toward...; A. Niezgoda, Badanie opinii...; M. Mika, Postawy spoteczności...

${ }^{22}$ R. Harrill, Residents' Attitudes toward...; A. Niezgoda, Badanie opinii ...; Y. Wang, R. Pfister, D. Morais, Residents Attitudes... 
Rysunek 1. Model Doxeya

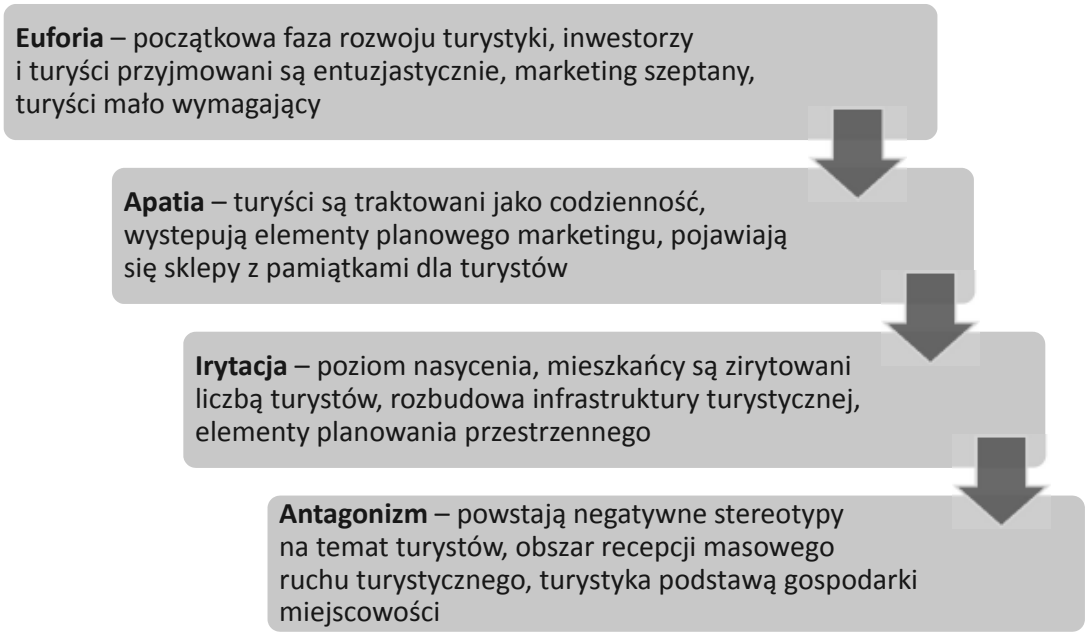

Źródło: opracowanie własne na podstawie: R. Harrill, Residents 'Attitudes toward..., s. 6-7; A. Niezgoda, Badanie opinii mieszkańców... s. 111; Y. Wang, R. Pfister, D. Morais, Residents Attitudes..., s. 412.

Model Doxeya jest jedną z prób przedstawienia zmian postaw mieszkańców wobec rozwoju turystyki w regionie. Można stwierdzić, że pokazuje on i uzasadnia konieczność prowadzenia badań dotyczących uwarunkowań społecznych związanych $\mathrm{z}$ rozwojem turystyki. W procesie planowania rozwoju turystyki w regionie wyniki tych badań mogą mieć istotny wpływ na powodzenie realizowanych działań z korzyścią dla środowiska i lokalnej społeczności.

Przegląd najnowszej literatury dotyczącej badań postaw mieszkańców wobec rozwoju turystyki pozwala na stwierdzenie, że najczęściej stosowane są metody ilościowe, a dane pozyskiwane są za pomocą badań ankietowych ${ }^{23}$. Bardzo

${ }^{23}$ D.R. Williams i in., Community attachment...; K. Komorowska, Turystyka a społeczności...; R. Harrill, Residents' Attitudes...; K.P.L. Chandralal, Impacts of Tourism ...; A. Niezgoda, Badanie opinii...; K.L. Andereck, G.P.S. Nyuapane, Exploring the Nature...; M.H. Hanafiah, M.A. Hemdi, Community Behaviour and Support...; N.M. Shariff, A.Z. Abidin, Community Attitude Towards Tourism Impacts: Developing a Standard Instrument in the Malasian Context, „ICSSR E-Journal of Social Science Research", 2013, s. 386-396; M. Mika, Postawy spoleczności...; A. Tucki, E. Skowronek, R. Krukowska, Ocena postaw...; Z. Głąbiński, Postrzeganie obszarów Natura 2000 przez mieszkańców nadmorskich terenów w Polsce w kontekście możliwości rozwoju turystyki, w: Zintegrowane Zarzadzanie Obszarami Przybrzeżnymi w Polsce - stan obecny i perspektywy, red. K. Furmańczyk, Z. Głąbiński, t. 5: Turystyka na nadmorskich obszarach Natura 2000, 
rzadko stosowane jest natomiast ujęcie jakościowe, w którym badacze wykorzystują indywidualne wywiady, zogniskowane wywiady grupowe lub obserwację uczestniczącą ${ }^{24}$.

W badaniach nad zjawiskami społecznymi związanymi z turystyką niektórzy badacze podkreślają konieczność stosowania różnych ujęć badawczych zarówno ilościowych, jak i jakościowych ${ }^{25}$. Interesującą opinię będącą uzasadnieniem dla prowadzenia badań o charakterze jakościowym prezentuje C. Trutkowski, który twierdzi, że „Aby zrozumieć, dlaczego ludzie dokonują określonych wyborów, należy ich o to zapytać i pozwolić im używać w odpowiedzi własnych kategorii - pozwolić im wskazać nam przyczyny ich zachowań i ich interpretacje przewidywanych rezultatów" 26 .

Jedną z coraz częściej stosowanych metod badań jakościowych są zogniskowane wywiady grupowe (ZWG). Zogniskowany wywiad grupowy, zwany zwyczajowo „fokusem” jest ,to nieformalna dyskusja grupy wybranych osób na wybrany temat odwołująca się do konkretnych sytuacji znanych tym osobom"27. Metoda ta polega na zgromadzeniu kilku (od 6 do 9 osób) w jednym miejscu i dyskusji na dany temat z udziałem moderatora. Jak podkreślają badacze, uzyskane w trakcie badania wyniki cechują się tzw. reprezentatywnością typologiczną ${ }^{28}$. Ponadto zwracają uwagę, że badania za pomocą zogniskowanych wywiadów grupowych są metodą jakościową i służą rozumieniu rzeczywistości, a nie

Szczecin 2014; J. Brankov i inni Sustainable Tourism in National...; I. Marković, Z. Klarić, Attitudes of Local...; B. Zeinali, M. Jafarpour, E. Omidi, N. Tahmasbi, S. Dorangard, Will Tourism....

${ }^{24}$ S.K. Gupta, V. Prakash, Assessment of rural...; T. Maneenetr, T.H. Tran, Local Community Participation in the Conservation of the Naga Fireball Festival, „Mediterranean Journal of Social Sciences" 2014, vol. 5, nr 23, s. 192-200.

25 A.H. Walle, Quantative versus qualitative tourism research, „Annals of Tourism Research" 1997, vol. 24, nr 3, s. 524-536; W. Alejziak, Metodologia badań w turystyce, w: Turystyka w naukach humanistycznych, red. R. Winiarski, Warszawa 2008; Z. Głąbiński, The application of social survey methods in analysing the tourist activity of seniors, „Bulletin of Geography. Socio-Economic Series" 2015, nr 27, s. 51-65.

${ }^{26}$ C. Trutkowski, Społeczne reprezentacje polityki, Budapest 1999, s. 6.

27 J. Lisek-Michalska, Badania fokusowe. Problemy metodologiczne i etyczne, Łódź 2013; Zogniskowany wywiad grupowy. Studia nad metodą, red. J. Lisek-Michalska, P. Daniłowicz, Łódź 2007, s. 16.

${ }^{28}$ D. Maison, Jakościowe metody badań marketingowych, Warszawa 2010, s. 18-21; J. Lisek-Michalska, Badania fokusowe..., s. 63. 
pomiarowi zjawisk i w odniesieniu do generalizacji uzyskanych wyników stwierdzają, że wnioski dotyczące znaczenia zjawisk i ich relacji można uogólniać29.

Z kolei jak podkreśla J. Lisek-Michalska fokusy powinny być stosowane w sytuacjach, gdy poszukujemy odpowiedzi na pytanie typu „dlaczego lub jak”30.

Uwzględniając powyższe opinie, zastosowano metodę ZWG do próby wyjaśnienia zarysowanego we wstępie problemu. Jednym z obszarów o znacznych walorach turystycznych jest powiat gryfiński, położony w zachodniej części województwa zachodniopomorskiego ${ }^{31}$. Lokalne władze są bardzo zainteresowane dalszym rozwojem turystyki w powiecie i poszukują odpowiedzi na pytanie dlaczego mimo posiadania znacznego potencjału turystycznego gospodarka turystyczna w powiecie gryfińskim rozwija się w wolnym tempie? W związku z tym niniejszy artykuł jest próbą uzyskania odpowiedzi na następujące pytania szczegółowe:

1. Jak osoby zaangażowane w rozwój turystyki w powiecie oceniają walory i infrastrukturę turystyczną powiatu oraz sposób ich wykorzystania?

2. Jaka jest ich ocena współpracy administracji publicznej, stowarzyszeń i przedsiębiorców na rzecz rozwoju turystyki w powiecie?

3. Jak te osoby oceniają rolę turystyki w gospodarce powiatu?

\section{Postrzeganie możliwości rozwoju turystyki przez mieszkańców powiatu gryfińskiego}

Badanie opinii społecznej z użyciem metody zogniskowanych wywiadów grupowych odbyło się we wrześniu 2015 roku. Zgodnie z opinią D. Maison ${ }^{32}$, aby uzyskać wiarygodne wyniki należy przeprowadzić min. dwa fokusy. Do udziału w badaniu zaproszono osoby związane zawodowo bądź w inny sposób zainteresowane rozwojem turystyki na terenie powiatu gryfińskiego. W Gryfinie wzięło udział w spotkaniu dwóch członków stowarzyszeń turystycznych NGO, dwóch przedsiębiorców turystycznych oraz trzech urzędników gminnych odpowiedzialnych za sprawy turystyki. W Moryniu było to dwóch przedsiębiorców, trzech

\footnotetext{
${ }^{29}$ D. Maison, Jakościowe metody..., s. 18-21.

${ }^{30}$ J. Lisek-Michalska, Badania fokusowe..., s. 61.

${ }^{31}$ M. Duda, T. Duda, Dolina Dolnej Odry...; Kanon krajoznawczy województwa zachodniopomorskiego, red. M. Duda, T. Duda, R. Śledziński, Szczecin 2014, s. 73-104.

${ }^{32}$ D. Maison, Zogniskowane wywiady grupowe. Jakościowa metoda badań marketingowych, Warszawa 2001, s. 65.
} 
działaczy lokalnych stowarzyszeń i czterech pracowników urzędów gmin. W ten sposób spełniono kryterium reprezentatywności typologicznej, gdyż w badaniu uczestniczyły osoby zamieszkałe na terenie powiatu i z największą wiedzą o warunkach i możliwościach rozwoju turystyki. Reprezentowanych przez nich opinii nie można traktować w kategoriach ilościowych, a jedynie jakościowych, a więc nie dają one odpowiedzi jaki odsetek mieszkańców podziela daną opinie. Jak podkreślają specjaliści badań społecznych, „z dużą dozą prawdopodobieństwa prezentują one najbardziej powszechne poglądy w analizowanym zakresie" ${ }^{33}$.

Obydwa fokusy prowadzone były zgodnie z opracowanym wcześniej scenariuszem, który zawierał wprowadzenie, zadawanie pytań, prowadzenie dyskusji, a po wyczerpaniu danego zagadnienia moderator dokonywał rekapitulacji prezentowanych poglądów i opinii. Czas trwania wywiadów wahał się od 100 do ok. 110 minut. Wywiady były nagrywane na dyktafon, a ponadto prowadzący oraz asystentka prowadzili notatki.

W następnym etapie, analizy zebranych informacji, przeprowadzono transkrypcję wszystkich wywiadów, które obejmowały od 32 do 36 stron tekstu standardowego formatu. W zaprezentowanej interpretacji treści ZWG wykorzystano cytaty, zachowując oryginalną stylistykę wypowiedzi.

\section{Ocena walorów turystycznych i infrastruktury oraz ich wykorzystanie}

\subsection{Walory turystyczne}

Ocena walorów turystycznych przez uczestników wywiadów jest ogólnie bardzo wysoka.

„Walory powiat gryfiński ma bardzo duże, poczynając od krajobrazu i natury po historię, tradycję, architekturę i zabytki”; „Mamy walory jedne z najpiękniejszych w Polsce”; „Na terenie naszego powiatu jak najbardziej są walory turystyczne, przyrodnicze i historyczne.”; „Walorów turystycznych, to ma chyba każda gmina”; „Jeśli chodzi o takie walory turystyczne, przyrodnicze no to jesteśmy naprawdę w czołówce".

Respondenci wskazywali, że dotyczy to szczególnie południowej i zachodniej części powiatu (Moryń, Cedynia, Mieszkowice, Chojna, Cedyński Park Krajobrazowy, Dolina Miłości, rezerwat Bielinek, Park Krajobrazowy Dolina Odry).

\footnotetext{
${ }^{33}$ Tamże, s. 65; J. Lisek-Michalska, Badania fokusowe..., s. 61.
} 
„Gmina Moryń ma nadmiar walorów przyrodniczych i historycznych”; „Jesteśmy położeni w terenie nadodrzańskim, więc na pewno rzeka Odra”; „Mamy piękne jeziora, mamy rzekę Odrę. To są wspaniałe walory. Rezerwaty przyrody, ptactwa, rezerwat Bielinek”; ,Jest pięknie ukształtowany, atrakcyjny krajobraz. Mamy Dolinę Miłości. Cała dolina dolnej Odry”; „Podobno są to jedne z najpiękniejszych ścieżek. Jesienią żółto-brązowe, wiosną piękna świeża zieleń. Po prostu szaleństwo, szaleństwo. Naprawdę można się zakochać".

Cytowane opinie zaprezentowali uczestnicy ZWG w Moryniu, miejscowości położonej w południowej części obszaru, której znaczną część obejmuje Cedyński Park Krajobrazowy - obszar o znacznych walorach przyrodniczych.

Badani podkreślali, że na terenie powiatu występują różnego typu walory o charakterze przyrodniczym.

„Mamy głównie walory przyrodnicze i to zarówno ta przyroda ożywiona jak i nieożywiona. No samo to ukształtowanie terenu związane z ostatnim zlodowaceniem, duże różnice wysokości”; „Walory są ogromne, tak, bo np. jest Puszcza Bukowa, jest ten cały Szczeciński Park Krajobrazowy”; „Walorem tutaj na pewno to jest jezioro Morzycko, no i w ogóle cały ten geopark”; „W Marwicach największe noclegowisko żurawi”.

Zwracali też uwagę na aspekty kulturowe (układy urbanistyczne, mury miejskie, kościoły oznaczone szachownicami, zamek w Swobnicy, miejsce bitwy pod Cedynią, Czelin, Gozdowice, Siekierki).

„Jak przyjechałem tutaj to wyjść z podziwu nie mogłem. Tu w co drugiej wsi jest kościół z XII albo XIII wieku”; „Piękne mury obronne przede wszystkim”; „Mamy skarby architektury rangi europejskiej, jeżeli nie światowej na terenie naszego powiatu. Przykładem jest architektura gotycka, to jest rzeczywiście gotyk najwyższej próby".

Pewne szczególne znaczenie mają w oczach mieszkańców miejsca wydarzeń historycznych

„Walory są historyczne związane z tym rejonem pamięci narodowej”; Wspomnę o rodzeniu się państwowości polskiej czyli bitwa pod Cedynią wojsk Mieszka I i jego brata Czcibora". 
Te głosy nawiązywały do ukształtowanego jeszcze w latach siedemdziesiątych XX wieku spojrzenia na historię regionu przez pryzmat zmagań Polaków i Niemców ${ }^{34}$.

Uczestnicy ZWG zwrócili także uwagę na związki pomiędzy walorami przyrodniczymi i kulturowymi.

„Historia też jest wpleciona tutaj jak gdyby w przyrodę”.

Jako przykład podają m.in. to, że:

„Walorem regionu są średniowieczne układy urbanistyczne (...) zresztą powiązane $\mathrm{z}$ historią geologiczną regionu, bo np. te budynki gospodarcze kamienne, kościoły kamienne".

Badani wskazują także na walory kulturowe powstające $\mathrm{z}$ udziałem mieszkańców:

„Właśnie te kulinaria, które tutaj powoli się pojawiają. Produkty tradycyjne tak jak właśnie te miody. Mamy w Baniewicach winnicę”; ,Walorem też są ludzie, tacy pasjonaci, którzy coraz częściej, coraz bardziej interesują się historią małej ojczyzny. Szukają jakiś ciekawostek".

Należy zwrócić uwagę, że badani wyróżnili walory o charakterze społecznym, powstające w obecnej rzeczywistości i zupełnie niezwiązane z wcześniejszą historią tego terenu.

Jako walor, nie tylko o charakterze turystycznym, jest postrzegany brak znacznego uprzemysłowienia powiatu:

„Mamy tutaj ciszę, spokój, zero przemysłu, nie mamy zanieczyszczeń środowiska”; „Najbardziej jestem za tym, że jest tu spokój”; „Żyją tutaj, nie wyjeżdżają. Ci, którzy nie wyjeżdżają to wiedzą, że tu fajnie żyć".

Mimo tych wszystkich bardzo pozytywnych ocen badani dostrzegają pewne mankamenty, które wpływają na ogólny obraz atrakcyjności turystycznej powiatu:

${ }^{34}$ T. Białecki, Garść wspomnień z obchodów tysięcznej rocznicy bitwy pod Cedynia, w: Cedynia i okolice poprzez wieki... s. 309-314. 
„Strasznie zaniedbana miejscowość i do dziś taka jest, bo te nasze małe miejscowości nie wyglądają jak z bajki po drugiej stronie Odry, nie. One są po prostu zaniedbane”; „Oczywiście te zabytki no nie są w zbyt dobrym stanie”.

Poglądy te nawiązują do wciąż aktualnej, mimo upływu lat opinii Z. Mazura, o negatywnym stosunku mieszkańców do obcego dla nich dziedzictwa kulturowego ${ }^{35}$. Z tego powodu znaczna część obiektów zabytkowych jest ciągle w złym stanie, chociaż ostatnio coraz więcej zmienia się na lepsze.

\subsection{Infrastruktura turystyczna}

Za jeden z najważniejszych współczesnych problemów związanych z turystyką w powiecie uczestnicy badania uważają bardzo słaby stan rozwoju infrastruktury turystycznej:

„Jest ogromny potencjał, który jest kompletnie niezagospodarowany”; „Turystycznie są tutaj czarne dziury, w które jak się wpadnie, to już się nie wyjdzie".

Uczestnicy badania wykazywali się również świadomością, że dysponowanie samymi walorami jest niewystarczające:

„Trzeba najpierw ławkę postawić, żeby gościa zaprosić”.

Zwracali też uwagę na nieodpowiedni sposób jej wykorzystania:

„Ta infrastruktura, która już istnieje jest np. źle wykorzystywana”.

Powyższe poglądy prezentowali wszyscy respondenci niezależnie od miejsca zamieszkania i zaangażowania zawodowego.

Głównym sygnalizowanym mankamentem jest brak rozwiniętej bazy hotelowej i gastronomicznej.

„Jest mało miejsc noclegowych. Słaba baza noclegowa. Nie ma tej całej bazy, parkingowej, noclegowej, gastronomicznej”; „Brak bazy noclegowej. To też jest mankament. Tutaj dość duży. No nie ma też zbyt wiele lokali gastronomicznych”; „Brakuje miejsc, gdzie można usiąść, zjeść, owszem są, ale jest ich niewiele, brakuje miejsc noclegowych"; My miejsc noclegowych, no nie mamy takich".

\footnotetext{
${ }^{35}$ Z. Mazur, Dziedzictwo wyłaczne....
} 
Nawet jeżeli teren jest udostępniony turystom, to i tak powtarzały się następujące opinie:

„Mają błękitną flagę, promenadę nad jeziorem, ścieżkę rowerową, ścieżkę nordic walking, nagle się okazało, że tam nie ma gdzie zjeść i gdzie przenocować".

Ponadto jeżeli istnieje baza noclegowa, to prezentuje niski standard:

„Dzisiaj, no np. ja jako turysta ja już nie mam ochoty mieszkać w takim domku kempingowym. Standard inny już się patrzy. I tego nam brakuje”.

Ważnym sposobem poznawania walorów turystycznych powiatu są ścieżki rowerowe. Niestety respondenci twierdzą, że ich sieć jest niewystarczająca:

„Są ścieżki rowerowe, z tym że według mnie jest ich stanowczo za mało. Są ścieżki nordic walking”; „Na samym już terenie Gryfina brakuje mi ścieżek rowerowych”.

Z kolei jeżeli już ścieżki istnieją, to są w złym stanie, bądź nie łączą się w spójną sieć albo nie spełniają oczekiwań turystów:

„Te ścieżki rowerowe są w fatalnym stanie. Nie ma infrastruktury, po prostu jeździ się ze ścieżki rowerowej w pewnym momencie wyjeżdża się na drogę leśną"; „Ścieżek rowerowych, to nie mamy w ogóle. Tematycznych też”; Żeby te ścieżki rowerowe były trafione, bo np. znam ścieżki rowerowe, które zostały zbudowane, w które włożono dużo pieniędzy i one dzisiaj trawą zarastają".

Tego typu uwagi zgłaszali przede wszystkim przedstawiciele NGO z Gryfina i Morynia zaangażowani w turystykę rowerową. Wskazują one na niedopracowanie przebiegu tras rowerowych do potrzeb ruchu turystycznego. Inwestorami tego typu infrastruktury prawie zawsze są urzędy gminne. Niestety urzędnicy odpowiedzialni za te działania nie zawsze mają odpowiednią, fachową wiedzę i często bez wystarczających konsultacji społecznych podejmują błędne decyzje.

Respondenci wskazują też, że dostęp do głównych atrakcji turystycznych powiatu jest utrudniony:

„Nawet «Krzywy Las» jest źle oznakowany”; „Mamy przepiękne kanały z bogatym też takim, no zasobem zwierząt, tak i roślinności, a nie mamy możliwości poruszania się po tym terenie". 
Ta sytuacja wynika m.in. z istniejących przez wiele lat ograniczeń w zakresie poruszania się w strefie przygranicznej, co spowodowało wieloletnie zapóźnienia $\mathrm{w}$ budowie infrastruktury turystycznej i do dziś utrudniają dostępność tych terenów dla ruchu turystycznego.

Poza elementami związanymi z turystyką poznawczą respondenci zwracali uwagę na braki dotyczące infrastruktury wypoczynkowej:

„Nie ma tutaj tej infrastruktury, tutaj nad wodą”; „Jest Gądno, to jest po prostu zaniedbane. Jest beznadziejna plaża”; „Tam na Gądnie są niewykończone budynki i ponad 20 lat straszą”; „Bo pięknie jest w Moryniu zrobione. Nie mniej jednak ta plaża jest mała i po prostu jest tam ścisk".

Co ciekawe na te mankamenty zwracali uwagę przede wszystkim przedstawiciele urzędów gmin i organizacji pozarządowych.

Choć Polska znajduje się w strefie Schengen to ze względu na Odrę, którą biegnie granica państwa, ważną kwestią jest dobra dostępność komunikacyjna powiatu od strony Niemiec:

„Bardzo dużym walorem tutaj naszych terenów jest istnienie dwóch, trzech bardzo dużych przejść granicznych z Niemcami. Chyba tego nie dostrzegamy, ale to jest potencjał dla tego terenu, ogromny. Trzeba zauważyć, że tak jak ktoś tutaj powiedział, że Berlin jest bliżej niż Szczecin".

Bliskość Berlina jako wielkiej aglomeracji generującej ruch turystyczny dostrzegali przedstawiciele południowej części powiatu, reprezentowani na spotkaniu w Moryniu. Ta ocena wynika z niewielkiej odległości do Berlina oraz dwóch dużych przejść granicznych na tym terenie. Ponadto należy zwrócić uwagę, że zmieniło się postrzeganie przygranicznej lokalizacji powiatu po 1989 roku. Traktowana jest obecnie bardziej jako czynnik korzystny dla rozwoju niż jego bariera. W ten sposób historia zatoczyła koło, ponieważ dolina dolnej Odry do czasu drugiej wojny światowej była naturalnym obszarem penetracji turystycznej mieszkańców Berlina. Dolina Miłości w Zatoni, Cedynia, Gryfino były miejscowościami licznie odwiedzanymi przez turystów m.in. dzięki istnieniu regularnej żeglugi pasażerskiej po Odrze i istnieniu odpowiedniej infrastruktury ${ }^{36}$.

\footnotetext{
${ }^{36}$ R. Matecki, Spacerem po Dolinie Miłości, Szczecin. 2013, s. 80-81; E. Włodarczyk, Gryfino w okresie dwudziestolecia międzywojennego, w: Dzieje Gryfina..., s. 153.
} 


\subsection{Sposób wykorzystania walorów i infrastruktury turystycznej}

Stopień wykorzystania i udostępnienia walorów jest oceniany dość nisko:

„Sposób ich wykorzystania wahałbym się czy określić jako dostateczny czy niedostateczny”; ,Jeśli chodzi o walory krajobrazowe, to po prostu żal. Żal tego, że są tak bardzo niewykorzystane w tym powiecie".

Z drugiej jednak strony badani zauważają, że niewielki ciągle jeszcze ruch turystyczny może być postrzegany jako zaleta:

„Można pokazać jezioro tutaj, na którym jest jeden kajak i piękna natura”.

Wśród ocenianych walorów wymieniane były tylko te o charakterze przyrodniczym, co jest kolejną przesłanką na głęboko zakorzenioną obojętność bądź niedostrzeganie zasobów kulturowych.

Respondenci przyczyn słabego wykorzystania walorów szukają przede wszystkim w świadomości mieszkańców, która wynika m.in. z zaszłości historycznych:

„My przywieźliśmy swoją historię tutaj i tak naprawdę nie do końca tę historię promujemy, która tutaj powstała. (...) My tu jesteśmy od 70 lat. Nie mamy tej historii, która by nas przyciągała".

Ta opinia doskonale potwierdza prezentowane we wstępie poglądy o wyjątkowości Pomorza Zachodniego. Mimo upływu ponad 70 lat od zakończenia drugiej wojny światowej w dalszym ciągu problem „oswojenia” się z zastanym dziedzictwem kulturowym dalej istnieje. Kolejne zdania umacniają ten pogląd. Respondenci stwierdzają też, że przyczyną braku zainteresowania eksploatacją walorów jest ich lekceważenie:

„Nie dostrzegają, może nie chcą dostrzegać. (...) Nie widzą, nie chcą widzieć, a po prostu może im to do niczego nie jest potrzebne”; „Nie są doceniane przez mieszkańców, a bardziej są doceniane przez turystów zachodnich, właśnie tu Niemców, czy turystów z większych miast”; „Mieszkańcy nie doceniają, taki obiekt Geopark”; „Ci mieszkańcy... nie doceniają tego jakie to Trzcińsko jest piękne”.

To zjawisko dotyczy również pracowników administracji samorządowej:

„Jest właśnie taki problem, że nawet sami pracownicy gmin poszczególnych, w tym mieszkańcy powiatu nawet nie wiedzą jakie mają tutaj atrakcje”. 
Niektórzy uczestnicy badania nawet sami przyznawali się do niskiego poziomu wiedzy na temat walorów powiatu:

„Bo po prostu nawet nie wiem jakie mamy do końca zabytki. Wstyd się przyznać”; „Chodzi tutaj o otoczenie Gryfina, bo reszta powiatu jest mi nieznana”.

Z tych wypowiedzi wynika, ze początkowo niechętny czy nawet wrogi stosunek do obcego dziedzictwa, ukształtowany w okresie powojennym bardzo powoli zmienia się na obojętny. Uczestnicy ZWG zwracali uwagę, że działania na rzecz rozwoju turystyki w powiecie należy zacząć od wzrostu poziomu świadomości:

„To uświadomienie mieszkańców i wszczepienie im tego, bo trzeba zacząć od mieszkańców, żebyśmy dalej promowali, muszą uwierzyć, że tu jest pięknie, że tu jest warto żyć”.

Niski poziom tożsamości regionalnej mieszkańców podkreślali wszyscy uczestnicy fokusów zarówno w Moryniu, jak i w Gryfinie. Ten pogląd znajduje potwierdzenie $\mathrm{w}$ prezentowanych we wstępie opiniach, że wśród mieszkańców Pomorza Zachodniego, którzy zostali przesiedleni na te tereny po zakończeniu drugiej wojny światowej a nawet kolejnych pokoleń, ciągle nie ukształtowała się nowa świadomość terytorialna ${ }^{37}$.

Zagadnienie budowania świadomości wiąże się z kwestią właściwej promocji walorów turystycznych, a to z kolei wpływa na wykorzystanie potencjału turystycznego powiatu. Niestety działania promocyjne są oceniane jako niewystarczające:

„Mamy walory, ale nie mamy jakby informacji, żeby zaprezentować te walory szerzej”; „Też jest słaba taka informacja turystyczna”; „Promocja jest taka jakbym nie wiem. W podziemiu. Tutaj przez przypadek ktoś się zatrzyma, bo przejeżdżał. Nie wiem. Zobaczył mury...?"

Przedstawione opinie nawiązują do poglądów reprezentowanych w literaturze, które podkreślają pozytywną rolę turystyki w kształtowaniu tożsamości terytorialnej. W sposób szczególny dotyczy to obszarów, gdzie turystyka jest słabo rozwinięta ${ }^{38}$. Kwintesencją tych poglądów jest dość smutna opinia: „Trzeba za-

${ }^{37}$ J. Leoński, Kilka socjologicznych..., s. 255-260.

${ }^{38}$ K.L. Andereck, G.P.S. Nyuapane, Exploring the Nature...; K.P.L. Chandralal, Impacts of Tourism...; M.H. Hanafiah, M.A. Hemdi, Community Behaviour and Support...; Y. Wang, R. Pfister, D. Morais, Residents Attitudes... 
błądzić, żeby tutaj przyjechać”. Nieco zaskakujące może wydawać się powyższe stwierdzenie, ale przywołuje ono sposób postrzegania tych ziem w czasach PRL. Wynika z tego, że mimo upływu lat i zasadniczej zmiany sytuacji społecznej, politycznej, w tym przynależności Polski do Unii Europejskiej, procesy adaptacji lokalnych społeczności do istniejących realiów przebiegają bardzo powoli i bardzo silnie wpływają na współczesną rzeczywistość. Przekształcenie ,ideologicznej ojczyzny” z czasów PRL w „małą ojczyznę” ciągle trwa.

\subsection{Ocena wspólpracy administracji publicznej, stowarzyszeń i przedsiębiorców na rzecz rozwoju turystyki w powiecie}

Ocena współpracy i koordynacji działań przez przedstawicieli samorządów jest jednoznacznie bardzo negatywna. Uczestnicy zauważają, że jest to poważny problem:

„Tej współpracy nie ma. My tak naprawdę się będziemy kisić w takim własnym sosie jakiś własnych niedomówień i braku współpracy. O tym należy mówić, ponieważ to jest dosyć poważny problem”; „Nie ma tak do końca współpracy, żebyśmy po prostu jako powiat gryfiński się promowali”; „Myślenie o tym, aby rzeczywiście te nasze gminy niekoniecznie się tak bardzo pokrywały, czyli znowu spójność, bo szkoda. Mogliśmy to rozłożyć na całe wakacje i byśmy mogli ludzi zabawiać w ten sposób".

Co więcej zamiast współpracy gminy ze sobą rywalizują. Zjawisko to jest również bardzo negatywnie postrzegane:

„Nie ma koordynacji w jakichkolwiek działaniach, jest wręcz konkurencja”; Bardzo rzadko zdarza się, żeby gminy ze sobą współpracowały, również w dziedzinie turystyki, czy promowania np. walorów”; ,Jak poprowadzić ścieżkę rowerową przez granicę gminy? Regułą jest raczej, buduję do granicy, a reszta mnie w ogóle nie obchodzi, niech oni się martwią".

Jako podstawowy problem we współpracy pomiędzy przedsiębiorcami branży turystycznej a administracją samorządową zgłaszany jest brak zaufania z obu stron:

„Możliwości często są, tylko gmina ani świat polityki nie ma zaufania do przedsiębiorców”; „Właścicielka pensjonatu robiła swoje i robi to świetnie, tylko dzięki sobie. Wsparcia z urzędu żadnego”; „Gdyby było takie systemowe rozwiązanie. Wspólna kooperacja urzędów i przedsiębiorców. Można zrobić jedno stoisko". 
Przedsiębiorcy raczej nie oczekują pomocy i są nastawieni sceptycznie do współpracy:

„Nic w ogóle nie mogę powiedzieć jako przedsiębiorca. Mam swoje plany, cele i je realizuję i tyle. $Z$ nikim nie współpracuję. Co mam do zrobienia to robię".

Stwierdzają jednak, że gdyby taka inicjatywa wyszła ze strony administracji samorządowej chętnie by do niej przystąpili:

„A jeżeli byłaby jakaś współpraca z gminą, też żeby ten turysta nie tylko do mnie przyjechał, przenocował, zjadł, ale też został w gminie , pochodził".

Ta dość pesymistyczna ocena współpracy uczestników badania wskazuje, że opinia J. Leońskiego jest ciągle aktualna: „Regionalizm zachodniopomorski istnieje na poziomie struktur instytucjonalnych i kultury oficjalnej. (...) Pomorze Zachodnie jest bardziej regionem w sensie administracyjnym niż świadomościo-

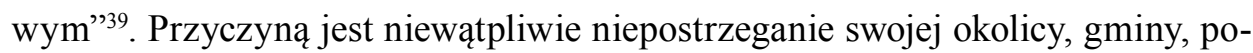
wiatu jako „małej ojczyzny”, jako wspólnego dobra, co wynika z dominującego, ambiwalentnego stosunku mieszkańców do otaczającego dziedzictwa.

Uczestnicy ZWG wskazują przede wszystkim na słabość organizacji pozarządowych działających na rzecz turystyki jako przyczynę braku korzystnej współpracy:

„Organizacji takich pozarządowych, turystycznych w gminie, no chyba w gminie już nie ma”; „Działających na naszym terenie organizacji pozarządowych jest mało. Ogólnie widać, że w społeczeństwie jest pewnego rodzaju marazm. Ludzie by dużo chcieli, ale mało jakby od siebie chcą dać”; „Współpraca się ciągle do pieniądza sprowadza".

Słabość organizacji pozarządowych, zdaniem badanych, wynika m.in. z braku świadomości, że turystyka może być ważną dziedziną życia w powiecie gryfińskim:

„Ludzie tutaj w ogóle nie myśleli o turystyce. Wydaje mi się, że nawet ludzie nie wiedzą o tym, że mogłoby coś powstać, bo z jednej strony się nie interesują, a z drugiej nie ma nigdzie żadnych wzmianek, gdzie mogliby się o tym dowiedzieć".

Jeżeli już takie organizacje istnieją i działają to:

\footnotetext{
${ }^{39}$ J. Leoński, Kilka socjologicznych..., s. 255-260.
} 
„Są albo słabe, bo liderzy, działają tak we własnym zakresie. Jak już są silniejsi no to zaczynają się przepychanki polityczne. Kto tutaj jest ważniejszy, zamiast współpracować. Konkurencja”.

Ze strony organizacji pozarządowych formułowane są zarzuty o braku woli współpracy ze strony władz samorządowych i sugestie co do zakresu współpracy:

„Zapraszamy radnych, burmistrza na te spotkania organizacji pozarządowych, żeby porozmawiać o turystyce. To bardzo szlachetnym milczeniem się odpowiada na to”; „Trzeba przypominać się, bo urząd może pomóc społecznikowi, a społecznik może urzędowi pewne wskazówki pokazać palcem. W każdym razie współpraca jest znikoma, a powinna być większa”.

Mimo tych wszystkich problemów i niedoskonałości dotyczących wspó1działania poszczególnych podmiotów, badani postulowali konieczność zmian i koordynacji współpracy na szczeblu powiatu:

„Brakuje takiego jakby organu, który by te organizacje pozarządowe czasami zwołał. Żeby ta współpraca nie była tylko na poziomie gminy, żeby powstawały dokumenty na poziomie powiatu i na poziomie województwa”; „Powiat jak najbardziej powinien w to inwestować i pracować nad współpracą, nad wymianą pomysłów i promocją tego regionu".

Zaprezentowane opinie wskazują, że przedsiębiorcy i przedstawiciele organizacji pozarządowych uważają, że na terenie powiatu gryfińskiego poziom partycypacji społecznej w rozwoju turystyki jest bardzo niski. Pozytywne znaczenie udziału społeczeństwa w kształtowaniu polityki turystycznej jest jednoznacznie podkreślane w literaturze ${ }^{40}$. Wzrost aktywności strony społecznej w tworzeniu i realizacji planów rozwoju turystyki ma zasadnicze znaczenie dla powodzenia tych działań. Niestety w ocenie znacznej części respondentów, na analizowanym obszarze władze w niedostatecznym stopniu rozumieją tę potrzebę.

\footnotetext{
${ }^{40}$ S.R., Arnstein, A Ladder of citizen participation, „Journal of the American Institute of Planners" 1969, vol. 35, nr 4, s. 216-224; R. Beunen, J.R., de Vries, The governance of Natura 2000 sites: the importance of initial choices in the organisation of planning processes, „Journal of Environmental Planning and Management” 2011, vol. 54, nr 8, s. 1041-1059.
} 


\subsection{Rola turystyki w gospodarce powiatu}

Również w ocenie roli turystyki w gospodarce powiatu kolejny raz pojawił się problem świadomości społecznej. Respondenci zwrócili uwagę, że warunkiem rozwoju turystyki jest wzrost świadomości mieszkańców:

„Nie było żadnego pomysłu na rozwój gmin czy regionów w kierunku turystyki”; „Ludzie tutaj w ogóle nie myśleli o turystyce. Ludzie po prostu całe swoje zapatrywanie upatrzyli sobie w tych przejściach granicznych”; „Absolutny brak świadomości. Turystyka nie jest traktowana jako biznes. Nie jest traktowana jako źródło dochodu gminy. To są upierdliwe obowiązki, które trzeba wykonać".

Uczestnicy badania postrzegają duży, ale ciągle niewykorzystany potencjał gospodarczy tkwiący w branży turystycznej:

„Problem polega na tym, ze możliwości są dużo większe niż to co się dzieje w tej chwili w naszym powiecie”; „Turystyka jest świetnym narzędziem do tego, żeby pomóc we wzroście zamożności mieszkańców i żeby gminy zaczęły się rozwijać"; „Może być narzędziem zarabiania".

Wskazują również, że turystyka mogłaby być głównym działem gospodarki powiatu. W optymistycznych scenariuszach uczestnicy badania nie widzą innych możliwości rozwoju niż turystyka:

„Jedynym kierunkiem rozwoju na przyszłość jest tylko turystyka”; „Ja myślę, że nasze tereny są skazane na to, żeby tą turystykę rozwijać. Tylko no musimy po prostu w tym kierunku iść”; „Musimy się nastawić i nie wiem czy ta turystyka nie powinna zajmować pierwszego, drugiego miejsca w hierarchii właśnie tych rzeczy, co ma nam przynosić dochód”; „Nie ma odwrotu dla tych terenów, bo jest się czym pochwalić".

Wśród osób o bardziej umiarkowanych poglądach opinie też są pozytywne:

„Rozwój turystyki jest jak najbardziej słuszny”; „Turystyka to jest biznes”; „To może być gałąź, która na przestrzeni lat będzie przynosiła jakieś zyski”.

Na szczególnie pozytywne postrzeganie znaczenia ekonomicznego turystyki na obszarach o słabym poziomie jej rozwoju zwracają uwagę m.in. I. Marković i Z. Klarić ${ }^{41}$. Zaprezentowane opinie jednoznacznie potwierdzają, że w powiecie

${ }^{41}$ I. Marković, Z. Klarić, Attitudes of Local..., s. 98-110. 
gryfińskim turystyka jest na początkowym etapie rozwoju i dlatego postrzegana jako jeden z najważniejszych czynników poprawy jakości życia.

W opinii zebranych należy podjąć zatem działania dążące do zmiany mentalności lokalnych społeczności:

„Teraz mieszkańcy muszą uwierzyć, a dalej możemy myśleć, które grupy chcemy przyciągnąć, jakich ludzi chcemy zainteresować, ale w to muszą być super zaangażowani również mieszkańcy".

Wśród proponowanych działań zwiększających zainteresowanie turystyką w powiecie wymieniana jest edukacja:

„Bo mieszkańcy tak jakby zostali informatorami, przewodnikami gminy. Bo bardzo brakuje jeszcze zainteresowania tu miejscowych. Dopiero to w tym kierunku idzie, ale to jeszcze za mała edukacja jest o tych walorach dla miejscowych".

Znaczenie roli edukacji w kształtowaniu pozytywnych postaw mieszkańców wobec otaczającego środowiska na przykładzie Pomorza Zachodniego zostało dobrze udokumentowane ${ }^{42}$. Przez szeroko zakrojone działania edukacyjne, można podjąć próbę zmiany nastawienia mieszkańców do otaczającej rzeczywistości. Oczywiście jest to proces długotrwały i wymagający koordynacji i zaangażowania władz oraz lokalnych liderów.

W toku dyskusji pojawiły się pomysły, na temat przykładowych segmentów rynku turystycznego, których przedstawiciele mogliby być najbardziej zainteresowani przyjazdem na teren powiatu gryfińskiego. Respondenci wskazują m.in. turystów jednodniowych o motywacjach poznawczych:

„U nas nigdy nie będzie turystów kilkudniowych. Musimy się nastawić na turystów jednodniowych a takich jest dużo”, „W naszej gminie to są z reguły turyści jednodniowi i coraz więcej znaczenia ma zamek w Swobnicy. Coraz więcej pojawia się osób z zagranicy".

Niezbędne jest więc przygotowanie kompleksowej oferty dla osób zainteresowanych turystyką aktywną:

„Chodzi o to, żeby on aktywnie spędził ten czas”; „Chcieliby aktywnie spędzić czas. Nie wiem, pewnie jakieś kajaki”; „Nie zatrzymamy kogoś przy jednym głazie, przy jednym pagórku, a $\mathrm{z}$ drugiej strony żadna z naszych gmin pojedynczo

\footnotetext{
${ }^{42}$ Z. Głąbiński, Szkolny ruch...,
} 
nie dysponuje aż tyloma atrakcjami, aby zatrzymać go długo, na tydzień, na dwa, w jednej gminie".

Jako trzeci segment wymieniana jest turystyka rodzinna:

„Jestem przekonany o tym, że jeżeli wziąć pod uwagę takie segmenty jak np. turystyka rodzinna, gdzie można razem z dziećmi spędzić kilka dni”.

\subsection{Działania służące rozwojowi turystyki}

W propozycjach zgłaszanych przez respondentów przeważają znane powszechnie postulaty związane z promocją:

„Trzeba by było dotrzeć do szerszej grupy tych osób, które mogłyby być zainteresowane odwiedzaniem takiego miejsca”; „Za mało na targach turystycznych bierzemy udział, za mało materiałów, folderów”.

Prezentowane były również pomysły ukierunkowane na określone segmenty rynku turystycznego: „Trzeba się odpowiednio zareklamować, sprzedać w nowoczesny sposób. Właśnie w prasie branżowej «Bike World» czy «Rower».

Gorąca dyskusja była poświęcona rozwojowi infrastruktury i współpracy. Największy problem stanowi brak:

„Systemowego spójnego działania, żeby spiąć to wszystko do kupy”; „Można by było stworzyć całą sieć infrastruktury turystycznej. Tak jak mówiliśmy szlaki rowerowe, szlaki kulinarne”; „Mnie się wydaje, że stworzenie takiego szlaku turystycznego może przynieść zyski dla każdego. Dla Gminy i dla nas też, dla przedsiębiorców”; „Potrzebna jest nam baza i atrakcje”.

$\mathrm{Na}$ zakończenie rozważań na temat roli turystyki w gospodarce powiatu można zaprezentować następujący pogląd prezentujący kwintesencję problemu: „Mamy sytuację absolutnego pata i błędnego koła. Nie ma turystów, więc nie ma inwestycji. Nie ma inwestycji więc nie ma turystów". Ta konkluzja potwierdza wcześniejszą konstatację, że głównym problemem w rozwoju turystyki, w ocenie respondentów, jest słaba współpraca pomiędzy zainteresowanymi stronami, która wynika z przedstawionych wcześniej uwarunkowań. 


\section{Dyskusja wyników - konfrontacja potencjału turystycznego i uwarunkowań społecznych}

Analiza zaprezentowanego materiału skłania do udzielenia odpowiedzi na przedstawione pytania badawcze.

Po pierwsze, powiat Gryfino dysponuje licznymi i znaczącymi walorami turystycznymi zarówno o charakterze przyrodniczym, jak i kulturowym. Niewątpliwie istniejąca infrastruktura turystyczna, szczególnie hotelowa jest niezbyt dobrze rozwinięta i nie pozwala na pełne wykorzystanie możliwości w zakresie przyjmowania turystów. Ponadto, mimo korzystnych uwarunkowań zewnętrznych, wynikających z sąsiedztwa dużych aglomeracji miejskich (Szczecin, Berlin) inne usługi turystyczne również nie są odpowiednio rozwinięte. Przyczyn tej sytuacji należy upatrywać przede wszystkim w ambiwalentnych postawach mieszkańców, którzy z jednej strony dostrzegają liczne walory turystyczne, szczególnie te o charakterze przyrodniczym, a z drugiej strony nie dostrzegają walorów kulturowych. Te postawy skutkują również brakiem woli współpracy pomiędzy władzami poszczególnych gmin a przedsiębiorcami turystycznymi i organizacjami pozarządowymi. To z kolei wpływa niekorzystnie na rozwój infrastruktury turystycznej i promocję poszczególnych gmin.

Przyczyn tego typu postaw wśród mieszkańców może być kilka. Jedną z nich są prawdopodobnie obawy przed wypromowaniem atrakcji turystycznych, które nie mogą być identyfikowane z historią Polski, czyli historią ojczyzny obecnych mieszkańców. Jak już wspomniano po zakończeniu drugiej wojny światowej nastąpiła na tym terenie całkowita wymiana ludności, a ponadto rzeka Odra, która była osią gospodarczą tego terenu, stała się rzeką graniczną pomiędzy Polską i Niemcami. Współcześnie obszary na zachód od Odry, w ocenie mieszkańców powiatu gryfińskiego, pod względem rozwoju turystyki znajdują się na zdecydowanie bardziej zawansowanym etapie. Ewolucja postaw mieszkańców wobec rozwoju, zgodnie z prezentowanym wcześniej modelem Doxeya, po wschodniej stronie Odry uległa przerwaniu. Istniejąca wcześniej na tym terenie infrastruktura turystyczna oraz wzorce zachowań społecznych uległy całkowitej zmianie. Do 1989 roku, czyli rozpoczęcia głębokich przemian społeczno-ekonomicznych w Polsce, na terenie obecnego powiatu gryfińskiego rozwijała się głównie turystyka, której celem było kształtowanie odpowiedniej postawy patriotycznej nowych mieszkańców tych terenów. Była ona inspirowana i sterowana przez ówczesne władze i miała służyć kształtowaniu tożsamości regionalnej nowych 
mieszkańców. W ten sposób jak stwierdza J. Leoński powstała tzw. tożsamość fasadowa, która cechuje się oderwaniem od rzeczywistości i koniecznością kierowania się zewnętrznymi nakazami ${ }^{43}$.

W związku z tym, po 1989 roku, gdy Polska weszła na drogę gospodarki wolnorynkowej i zabrakło czynników polityczno-administracyjnych sterujących turystyką nastąpiło załamanie dotychczasowego modelu rozwoju turystyki na tym terenie. Rozpoczął się nowy etap jej rozwoju, który trwa do dzisiaj. Mieszkańcy obecnie budują nową tożsamość, a zatem również kształtują się ich nowe postawy wobec rozwoju sektora turystycznego. Nawiązując do opinii D.R. Williamsa i in. można zauważyć, że obecni mieszkańcy bardziej identyfikują się z walorami turystycznymi o charakterze przyrodniczym niż z walorami kulturowymi ${ }^{44}$. Sytuacja ta się jednak zmienia, czego dowodem są pozytywne wypowiedzi niektórych mieszkańców dotyczące dziedzictwa kulturowego. Dla pasjonatów turystyki krajoznawczej oraz urodzonych i wychowanych na tym terenie to ich „mała ojczyna”.

Kolejnym czynnikiem sprzyjającym zmianom postaw wobec istniejących walorów, a co za tym idzie rozwoju turystyki jest przystąpienie Polski do Unii Europejskiej w 2004 roku. Granica na Odrze między Polską a Niemcami powoli przestaje dzielić i powstają coraz liczniejsze wspólne, transgraniczne inicjatywy współpracy. W związku z tym m.in. na terenie powiatu wytyczono odcinki europejskich szlaków tematycznych: Europejskiego Szlaku Gotyku Ceglanego, Szlaku Cysterskiego oraz Szlaków Templariuszy i Joannitów. Te działania spowodowały, że coraz częściej mieszkańcy uznają, że dziedzictwo kulturowe tego terenu jest częścią dorobku kulturowego Europy. Kultura europejska jest naszym wspólnym dziedzictwem, a więc również obecnych mieszkańców powiatu gryfińskiego.

Należy się zatem spodziewać, że teren dysponujący tak bogatymi walorami turystycznymi wejdzie już wkrótce na ścieżkę rozwoju turystyki, a przy odpowiednim działaniu władz lokalnych, uwzględniającym interesy lokalnej społeczności, będzie to turystyka dostosowana do szczególnych uwarunkowań przyrodniczych i kulturowych tego obszaru.

${ }^{43}$ J. Leoński, Kilka socjologicznych..., s. 255-260.

${ }^{44}$ D.R. Williams, C.D. McDonald, C. Riden, M. Uysal, Community attachment..., s. 425. 


\section{Literatura}

Alejziak W., Metodologia badań w turystyce, w: Turystyka w naukach humanistycznych, red. R. Winiarski, Warszawa 2008.

Andereck K.L., Nyuapane G.P.S., Exploring the Nature of Tourism and Quality of Life Perception among Residents, ,Journal of Travel Research” 2011, vol. 50, nr 3.

Arnstein S.R., A Ladder Of Citizen Participation, „Journal of the American Institute of Planners" 1969, vol. 35, nr 4.

Białecki T., Garść wspomnień z obchodów tysięcznej rocznicy bitwy pod Cedynia, w: Cedynia i okolice poprzez wieki, red. P. Migdalski, Chojna-Szczecin 2013.

Beunen R., de Vries J.R., The governance of Natura 2000 sites: the importance of initial choices in the organisation of planning processes, „Journal of Environmental Planning and Management" 2011, vol. 54, nr 8.

Brankov J., Jovičić D., Milijašević D., Sustainable Tourism in National Park Derdap, Serbia - Attitudes of Local Population, „Journal of the Geographical Institute Jovan Cvijic" 2015, nr 65 (2).

Chandralal K.P.L., Impacts of Tourism and Community Attitude towards Tourism: A Case Study in Sri Lanka, „South Asian Journal of Tourism and Heritage” 2010, vol. 3, nr 2.

Czejarek R., Swobnica, Szczecin 2013.

Duda M., Duda T., Dolina Dolnej Odry - przewodnik krajoznawczy dla aktywnych, Gdynia 2008.

Dźwigał M., Granica, w: Spacerem po Dolinie Miłości, red. R. Matecki, Szczecin 2013.

Filipowiak M., Piekarz K., Rybak P., Z dziejów organizacji służby granicznej w Cedyni (1945-2003), w: Cedynia i okolice poprzez wieki, red. P. Migdalski, Chojna-Szcze$\operatorname{cin} 2013$.

Głąbiński Z., Szkolny ruch turystyczno-krajoznawczy jako czynnik kształtowania tożsamości regionalnej na przykładzie województwa zachodniopomorskiego, Szczecin 2008.

Głąbiński Z., Postrzeganie obszarów Natura 2000 przez mieszkańców nadmorskich terenów w Polsce $w$ kontekście możliwości rozwoju turystyki, w: Zintegrowane Zarzadzanie Obszarami Przybrzeżnymi w Polsce - stan obecny i perspektywy, red. K. Furmańczyk, Z. Głąbiński, t. 5: Turystyka na nadmorskich obszarach Natura 2000, Szczecin 2014.

Głąbiński Z., The application of social survey methods in analysing the tourist activity of seniors, „Bulletin of Geography. Socio-Economic Series” 2015, nr 27, DOI: http:// dx.doi.org/10.1515/bog-2015-0004.

Gupta S.K., Prakash V., Assessment of rural destination residents' attitude toward tourism development in Uttarakhand, India: a research note, „International Journal of Qualitative Research in Services" 2014, vol. 1, nr 3. 
Hanafiah M.H., Hemdi M.A., Community Behaviour and Support towards Island Tourism Development, „International Journal of Social, Behavioral, Educational, Economic, Business and Industrial Engineering” 2014, vol. 8, nr 3.

Harrill R., Residents' Attitudes toward Tourism Development: A Literature Review with Implications for Tourism Planning, ,Journal of Planning Literature” 2004, vol. 18, nr 1.

Kanon krajoznawczy województwa zachodniopomorskiego, red. M. Duda, T. Duda, R. Śledziński, Szczecin 2014.

Komorowska K., Turystyka a społeczności lokalne - przykład tatrzański, „Studia Regionalne i Lokalne" 2003, nr 3 (13).

Leoński J., Kilka socjologicznych uwag o świadomości regionalnej mieszkańców Pomorza Zachodniego, w: Integracja i tożsamość. Zachodniopomorskie $w$ przededniu rozszerzenia Unii Europejskiej, Materiały I Kongresu Zachodniopomorskiego. Szczecin 2003.

Lisek-Michalska J., Badania fokusowe. Problemy metodologiczne i etyczne, Łódź 2013.

Maison D., Zogniskowane wywiady grupowe. Jakościowa metoda badań marketingowych, Warszawa 2001.

Maison D., Jakościowe metody badań marketingowych, Warszawa 2010.

Makowski A., Dzieje miasta w Polsce Ludowej, w: Dzieje Gryfina i okolic, red. P. Kołosowski, Gryfino 2009

Makowski A., Cedynia ofiara ,zimnej wojny”?, w: Cedynia i okolice poprzez wieki, red. P. Migdalski, Chojna-Szczecin 2013.

Maneenetr T., Tran T.H., Local Community Participation in the Conservation of the Naga Fireball Festival, „Mediterranean Journal of Social Sciences” 2014, vol. 5, nr 23.

Marković I., Klarić Z., Attitudes of Local Population of Tourism Impacts on Destination Sustainability - Case of Croatia, „Turizam” 2015, vol. 19, z. 3.

Matecki R., Spacerem po Dolinie Miłości, Szczecin 2013.

Mazur Z., Dziedzictwo wyłączne, podzielone, wspólne, w: Ze studiów nad stosunkiem spuścizny kulturowej na Ziemiach Zachodnich i Pótnocnych, red. Z. Mazur, Poznań 2000.

Mika M., Postawy społeczności lokalnych wobec turystów i rozwoju turystyki - przykład gmin Beskidu Ślaskiego, „Prace Geograficzne IG i GP” 2013, z. 134.

Niezgoda A., Badanie opinii mieszkańców Poznania dotyczacych rozwoju funkcji turystycznej, w: Sposoby mierzenia i uwarunkowania rozwoju funkcji turystycznej miasta, red. G. Gołembski, Poznań 2011.

Nyuapane G.P., Poudel S., Linkage Among Biodiversity, Livelihood, and Tourism, „Annals of Tourism Research" 2011, vol. 38, nr 4.

Rogacki H., Przesunięcia w strukturze i hierarchii miast województwa zachodniopomorskiego w latach 1810-2000, „Przegląd Zachodniopomorski” 2003, z. 4. 
Shariff N.M., Abidin A.Z., Community Attitude Towards Tourism Impacts: Developing a Standard Instrument in the Malasian Context, „ICSSR E-Journal of Social Science Research" 2013.

Sharpley R., Turystyka i środowisko, w: Zarządzanie turystyka, red. L. Pender, R. Sharpley, Warszawa 2008.

Sikorska-Wolak I., Zawadka J., Postawy społeczności lokalnej wobec rozwoju turystyki wiejskiej, „Folia Pomeranae Universitatis Technologiae Stetiniensis. Oeconomica” 2011, nr 288 (64).

Strategia rozwoju turystyki na poziomie lokalnym. Przykład powiatu gryfińskiego, red.

Z. Głąbiński, D. Szostak, T. Zalewski, Warszawa 2016.

Trutkowski C., Społeczne reprezentacje polityki, Budapest 1999.

Tucki A., Skowronek E., Krukowska R., Ocena postaw społeczności lokalnej do rozwoju turystyki na przykładzie Zwierzyńca, w: Gospodarka turystyczna w regionie. Rynek turystyczny - współczesne trendy, problemy i perspektywy jego rozwoju, red.

A. Rapacz, Wrocław 2013.

Walle A.H., Quantative versus qualitative tourism research, „Annals of Tourism Research" 1997, vol. 24, nr 3.

Wang Y., Pfister R., Morais D., Residents Attitudes Toward Tourism Development: A Case Study of Washington, NC, „Proceedings of the 2006 Northeastern Recreation Research Symposium" 2006.

Williams D.R., McDonald C.D., Riden C., Uysal M., Community attachment, regional identity and resident attitudes toward tourism, „Proceeding of the 26th Annual Travel and Tourism Research Association Conference” 1995.

Włodarczyk E., Gryfino w okresie dwudziestolecia międzywojennego, w: Dzieje Gryfina i okolic, red. P. Kołosowski, Gryfino 2009.

Zeinali B., Jafarpour M., Omidi E., Tahmasbi N., Dorangard S., Will Tourism Development Improve the Quality of Life in Hashtpar City? An Analysis of Local Residents' Attitudes, „International Journal of Economy, Management and Social Sciences” 2015, vol. 4, nr 3.

Zogniskowany wywiad grupowy. Studia nad metoda, red. J. Lisek-Michalska, P. Daniłowicz, Łódź 2007.

\section{Abstrakt}

Turystyka jest postrzegana przez coraz większą liczbę mieszkańców różnych krajów jako szansa na rozwój lokalnej gospodarki i poprawę jakości życia. Mimo że powiat gryfiński dysponuje bardzo dużymi walorami turystycznymi zarówno o charakterze przyrodniczym, jak i kulturowym, a ponadto ma korzystne położenie geograficzne, turystyka 
rozwija się bardzo powoli. W celu ustalenia przyczyn istniejącej sytuacji podjęto próbę zbadania opinii lokalnej społeczności na ten temat za pomocą metody zogniskowanych wywiadów grupowych. Uzyskane wyniki wskazują na podstawowe znaczenie postaw mieszkańców wobec rozwoju turystyki w regionie.

\title{
The Relationship between the Marriages of the Gryfino County AND THE Development of TOURISM in the Light of Qualitative Research
}

\begin{abstract}
Tourism is perceived by more and more people in different countries as a chance for the development of their local economy and a chance for an improvement of the quality of life. In spite of the fact that there are many touristic attractions, both natural and cultural, in the Gryfino County, and in spite of its attractive geographical situation the pace of its touristic development is rather slow. In order to investigate the reasons for the situation research has been initiated based on the method of focused group interviews. The results indicate that the basic factor is the attitude of the inhabitants of the region towards the development of tourism.
\end{abstract}

